\title{
Improvement of the Regulatory Framework of Regulation of Transnational Business in Azerbaijan
}

\author{
Muslumat Allahverdiyeva ${ }^{1}$ \\ 1PhD in Economics, Assistant Professor of Department of "Economy and management" \\ AZ1001, Baku, Istiglaliyyat str.6, e-mail: allahverdiyeva_muslumat@mail.ru
}

\section{Sekine Huseynova ${ }^{2}$}

2PhD in Economics, Assistant Professor of Department of chair of organization of tradeand customs,Azerbaijan State Economic University (UNEC), AZ1001,Baku, Istiglaliyyat str.6.e-mail: sekineyaqubqizi@mail.ru

\section{Matanat Dadashova ${ }^{3}$}

2PhD in Economics, Assistant Professor of Department of chair of organization of tradeand customs,Azerbaijan State Economic University (UNEC), AZ1001,Baku, Istiglaliyyat str.6.e-mail:dadashova64@mail.ru

Article History: Received: 10 November 2020; Revised 12 January 2021; Accepted: 27 January 2021; Published online: 5 April 2021

\section{Summary}

Though formation of the transnational business is based on common principles, this process appears in a specific form in various countries. Transnational business is different depending on the structure of the economy, the level of socio-economic development, organizational and management structure, national-ethnic characteristics, and the level of development of the state in various countries. At the same time, creating and justifying the fact that big, fast-growing and concentrated national companies are ranked in the rankings as TNB (transnational business) is one of the issues within the interest of state and economic science. Upon the Contract of the Century signed in September 1994, Azerbaijan has subsequently signed the production sharing agreements (PSAs) on "Garabakh", "Dan ulduzu" and "Ashrafi" fields. The biggest TNBs, such as BP, Amoko, Penzoil and Unocal, have their share in oil fields from Azerbaijan. Up to $70 \%$ of all investments in the Azerbaijani economy are invested in the oil industry, about $80 \%$ of which is imposed by the foreign TNBs. This figure indicates that the TNB has a great role in the economy of Azerbaijan.

TNB has both positive and negative impacts on the economy of Azerbaijan. As Azerbaijan's transnational business develops, various problems also arise. For instance, the problems between the TNB and the Azerbaijan Trade Unions Department, the problems between Britis Petrolium and the Azerbaijan Government, etc. The problems they face with the host countries have begun to show itself in Azerbaijan too. Transnational business regulation is a very urgent issue over the world. The scientists have increasingly investigated the legal aspects of the TNB regulation. This article is dedicated to the actions that are being taken and important to be taken to regulate transnational business at the state level in the Republic of Azerbaijan, and the regulation methodology is proposed.

Key words: transnational business, regulation, regulator acts, Azerbaijan, Production Sharing, 


\section{Introduction and study of the problem}

The problems covered by the Article. As the transnational business in Azerbaijan develops, various problems also arise. Since 1994, the problems that the TNB has with its host countries have begun to show itself in Azerbaijan. Transnational business regulation is a very urgent issue over the world. The scientists have increasingly investigated the legal aspects of the TNB regulation. The researches conducted show that the international regulatory measures, as well as the national legislation, are weak to regulate these "monsters", supernuclear companies.

Theoretical and practical importance of the Article. Methods and approaches. The present article has been prepared under the economic theories of the classics in this field, the studies carried out by the modern western and local scientists in the field of regulation of transnational business and transnational companies, various legal documents and regulations adopted by the republic government in accordance with the subject of the research.

Problem study level and literature summary. The scientists from the Western and PostSoviet region have made their significant contributions with their studies of transnational business wholly and its individual sub-systems (transnational company). In the recent years, the local scientists have also made very interesting researches in the field of transnational business regulation and transnational companies. The following definition of the multinational companies are mostly found in special legal literature. TNB is formed by the combination of various independent businesses located in different countries and managed from a common center united for the same economic purpose. Unlike ordinary companies, the operating strategies of TNB are produced by a parent company that coordinates the activities of its subsidiaries.

With regard to the growing economic and political influence of the TNBs, the scientific literature discusses the necessity of recognition of the TMB as a subject of international law. The foreign scientists N.MacDougal and W.Friedman think that the TNBs are subjects of international law. The views of the Russian scientists on this are different. (MacDougall, G.D.A. 1960). For example, V.A.Romanov and S.V.Chernichenko claims that only the institutions that can participate in interstate relations may be subject of international law. Since the company does not have state-specific qualities, its participation is not possible in such relationships. (Черниченко C.B. 1999.). I.I.Lukashuk also considers granting the status of international law to corporations unrealistic. (Lukashuk I.I. 2000). According to Lokaychuk O.V., in the twenty-first century, increase of powers and functions that may lead to the recognition of a legal entity occurs in a big TNB, a collective body. He noted that I consider the notion of "international corporate law" based on contracts between corporations and states. For example, the English professor B.Cheng proposes formation of special legal systems that are outside national norms and treaties which comply with international law or common law principles. However, this concept has not yet supported by scientists. Accordingly, V.Romanov and S.Chernichenko consider that the agreements concluded between states and companies are not interstate treaties, but civil transactions and are related to the private international law. I.I. Lukashuk claims that a company cannot be exempted from state law. However, it also emphasizes that the TNBs could not create a special legal system. 
From this point, other ideas are also encountered in the literature. In the 1970s, famous American economists R.Mason, R.Miller, and D.Weigel came to the conclusion that the international activities of the US corporations undermined the structure of global economic ties to capitalism. At the same time, the Russian scientist I.I. Lukashuk does not support statements about the diminished role of the state in international relations. As for him, the increasing presence of commercial and public organizations, movements and individuals in international relations makes it difficult to manage these relationships. In addition, the idea of diminishing the role of a state in the international relations is rejected by the famous practical scientist B.B.Ghali. Ghali B.B. stressed that a sovereign state is essential and matchless as the main subject of international law. (Boutros Boutros-Ghali, 2016.).

Thus, the scientists and practitioners express very different views. In my opinion, the most favorable ideas are those of the Russian scientists V.A.Romanov, S.V.Chernichenko and I.I.Lukashuk. They completely reject the proposal to transfer some of the state powers to the TNBs and recognize them as full-fledged subjects of international law. A state fulfills the functions such as tax collection, social protection and labor protection, environmental protection, antitrust activity from the point of the public interest. TNBs pursue private capital interests. All their activities are aimed at achieving economic profit.

Therefore, unlike the state, they will not be able to govern their activities for the benefit of the whole society. On the contrary, violations of statehood, labor, tax laws and environmental standards of their countries of origin, their limited business practices, their cosmopolitanism, caused increase of conflicts between TNBs on one hand, and between origin and host country on the other hand. Therefore, legal regulation of TNB activity at the international level and increasing of the effectiveness of its control are of the the main priority issues.

Natalukha V.V., the authoritative expert in the field of private international law, defines three levels of legal regulation of TNBs: domestic legislation, bilateral and multilateral agreements. (Natalukha V.V., 2005)

\section{Analysis of theoretical-methodological and practical aspects of the regulatory framework of regulation of the transnational business in Azerbaijan}

In the 1990s, the Azerbaijani Government started to implement reforms during the independence period in order to overcome the economic closeness remained from the Soviet time. Firstly, the state monopoly on foreign trade was cancelled. Liberalization of foreign economic activity as the main direction of foreign economic policy, and thus use of market mechanisms were allowed. A system of state regulation of foreign trade and currency flow was formed. This system allowed economic entities to conduct free foreign trade operations on one hand and to control the state in terms of import-export and currency operations on the other hand. However, at the initial terms, the Republic faced with a number of difficulties.

So, there was a shortage of foreign trade personnel, customs and currency authorities, legislative base, inspectorates and other infrastructure were not fully formed. While the country imposed certain restrictions on import and export in 1992-1993, the state changed its strategy in the area of foreign trade in 1994 and the government assumed this function.

According to the Decree of the President of the Republic of Azerbaijan "on Liberalization of Foreign Trade" dated April 5, 1994, the strategically important goods (oil, 
oil products, ferrous and nonferrous metals, aluminum, chemical products, cotton products, etc.) that constitute the basis of the country's export capacity, were allowed to be freely exported by all legal entities from the Republic.

Gradually, the infrastructure of foreign economic relations and the normative base of personnel training were formed. Foreign trade licensing, quotas and various non-tariff instruments were cancelled. Now the economic entities freely choose markets and partners and independently bear responsibility for the results of operations. (T. Huseynov, 2010).

Joint development of natural resources in Azerbaijan with foreign companies is based on "Production Sharing Agreement". The foreign company acts as a contractor and subcontractor. It receives a share of the goods produced in return for its provided services and performed works. The advantage of the product sharing agreement for the national state is that it allows for a high level of control over the operations of a foreign company. Multiple production sharing agreements were signed with foreign companies to jointly exploit oil and gas, non-ferrous metals and iron ore deposits in Azerbaijan. According to these contracts, a foreign company performs the work stipulated by the contract at its own expense.

A foreign company does not receive economic benefits from its investments alone. It receives a share of the profit obtained from sale of its products at the rate pror specified in the contract.

In accordance with the Law of the Republic of Azerbaijan "on Protection of Foreign Investments", a joint venture, including foreign company may be established. In this case, joint ventures and foreign companies have the status of legal entities of the Republic of Azerbaijan. Their organizational and legal forms (joint stock company, limited liability company, etc.) may differ. Foreign partners can withdraw their shares from the country both in cash and in the form of products. ${ }^{1}$

The benefit of the host country is that advanced technologies, equipment, modern management practices of foreign countries are imported to the country, products repacing import are produced, and export potential is increased.

A number of joint ventures and foreign companies were established in Azerbaijan over the years of independence. As provided in the Table 1.1, about $67 \%$ of industrial output (including the oil and gas sector) in the country was produced in joint ventures and foreign companies in 2016. Although the number of employees declined in comparison with the year 2015 , production increased by 5.3 billion manat. The average monthly salary of workers working there is 3464 manats and this was 3.7 times higher than the average on the industry. The number of joint ventures and foreign companies increased 1.2 times in comparison with the year 2015. The rapid growth of macroeconomic indicators of joint ventures and foreign companies reflects the favorable environment for transnational business in Azerbaijan.

${ }^{1}$ Law of the Republic of Azerbaijan "on Protection of Foreign Investments". 
Table 1.

Inficators of joint and foreign industrial companies in Azerbaijan

\begin{tabular}{|l|l|c|c|c|}
\hline No. & Indicators operating & 2065 & 2015 & 2016 \\
\hline $\begin{array}{l}\text { Number of } \\
\text { companies }\end{array}$ & $\begin{array}{l}\text { Number of their employees, } \\
\text { thousand person }\end{array}$ & 23.6 & 24.8 & 234 \\
\hline $\begin{array}{l}\text { Average monthly salary, } \\
\text { man }\end{array}$ & $\begin{array}{l}\text { Volume of product (work } \\
\text { and service), mil. man }\end{array}$ & 5172 & 2594 & 3464 \\
\hline $\begin{array}{l}\text { Including special weight in } \\
\text { total industrial product, \%-lə }\end{array}$ & 55.6 & 61.2 & 66.5 \\
\hline
\end{tabular}

Source: "Statistical indicators in Azerbaijan", State Statistical Committee, 2017, p.130-131.

According to the Law on Subsoil, the rights and obligations of a user of subsoil come into force from the time of issue of a special permission (license) as specified. ${ }^{2}$ Unlike some post-Soviet republics (for example, the Russian Federation), the subsoil in Azerbaijan is kept under state ownership, and foreign companies are only allowed to use it. The term of use of the subsoil is also specified by law. So, it is specified 5 years for geological exploration of the subsoil, 25 years for production of natural resources and 30 years for geological exploration and extraction. Different payments are made for the use of the subsoil.

The Contract of the Century that covers exploration, exploitation and production sharing of the Azeri-Chirag-Guneshli (ACG) fields, specifies direct distribution of profits. The importance of the distribution system is that a foreign company, after compensating its capital and operating costs, distributes profit oil with the proportions of the Azerbaijani state. Foreign companies are exempt from other taxes and pay profit tax only.

According to the Article 22 of the Contract, when foreign compaies sell their shares in the Contract, their sale is not subject to income tax. ${ }^{3}$ Azerbaijan reimburses the expenses of all foreign employees participating in the project (Article 12 of the Contract). The Contract specifies payment of bonus of USD 300 million to Azerbaijan for 500 million tons of confirmed oil reserve.

Distribution of oil between foreign companies and Azerbaijan is specified by the Contract from the time of commencement of production. And this allowed Azerbaijan to obtain a benefit from the first ton of production. But here is an important point to note. The start of production from three oil fields included in a single contract has been planned for various years. For example, the first oil production in the Chirag field was agreed in 1997, in Central Azeri in 2005, and in Guneshli in 2008. The foreign contractor using this case has used the bulk revenue generated from oil produced from the Chirag field at Azeri field for 7

\footnotetext{
${ }^{2}$ Law of the Republic of Azerbaijan on Subsoil.

3 "Contract of the Century", 1994
} 
years (up to 2005). The same approach has also been repeated in Central Azeri. As a result, Azerbaijan's part of profit oil, as well as its share, decreased.

The Contract of the Century also defines the procedure for compensation of contractor's costs (Article 11.2). So that, the operating costs of the contractor (International Operating Company) are covered from the total amount of oil produced. The remaining 50\% of crude oil is spent on capital expenditures. The remaining crude oil is considered as profit oil and is distributed among the participants on a quarterly basis. Each participant may sell their shares independently.

Pursuant to the paragraph 11.4 of the Contract, the contractor is allowed to transfer current operation and capital expenditures that were not paid in the previous quarter of the work, to the following quarters. This right also remains in force for 30 years the contract lasts. This is a different legal norm than "Tax Code of the Republic of Azerbaijan". Because the Code specifies that legal entities may use this right for 3 years. ${ }^{4}$

Up to 10 percent of the oil produced in accordance with "the Contract of the Century" (paragraph 11.1) may be used by the contractor for free, non-repayable production purposes (to maintain the stable pressure in oil wells, etc.).

Unlike the Tax Code of Azerbaijan, one of the provisions in the Contract of the Century is the calculation of depreciation deductions. This applies to both the depreciation rate and the classification of fixed assets.

First of all, the classification of the fixed assets is different from both the international and Azerbaijani standards:

Foreign companies, as a rule, use rapid depreciation. So, they include depreciation deductions as the expense item for the product's cost using the procedure specified in the Tax Code of Azerbaijan. In the international practice, depreciation deductions are not considered an expense item and a profit of company. It should also be noted that depreciation deductions in the consolidated financial balance and National Accounts of Azerbaijan are considered as the profits of economic entities. Thus, there is a discrepancy between the three state documents of Azerbaijan.

Unlike other post-Soviet republics (Russia, Kazakhstan), the deposits of natural resources, that is, the subsoil, jointly used with foreign companies, are the property of Azerbaijan, and the state is actively involved in these activities. Joint ventures are established in Azerbaijan with the participation of relevant economic subjects.

In the international practice, direct and indirect regulatory indicators are used for the purpose to regulate transnational business. Foreign trade turnover, export and import quotas, and import and export efficiency (profitability) indicators are of such ones.

According to "Rules of Regulation of Import and Export Operations in the Republic of Azerbaijan" approved by the Presidential Decree, the persons are free to export the goods produced, processed and re-processed in Azerbaijan, and their activity should not be restricted except for the goods stipulated by the Customs Code (paragraph 1.1). [6]

Implementation of import-export operations by all residents and non-residents in the Republic of Azerbaijan shall be governed by these Rules.

${ }^{4}$.Decree on "Rules of regulation of import-export operations in the Republic f Azerbaijan" 
Import and export operations stipulated by the Interstate Agreements are carried out in accordance with the relevant decisions and orders of the Cabinet of Ministers of the Republic of Azerbaijan (section IV).

The nomenclature (list of works, services) of the goods subject to export control is approved by the president of the country on the proposal of the Cabinet of Ministers in accordance with the Law on Export Control. ${ }^{5}$

In order to regulate the commodity structure of imports, to provide an optimal ratio of foreign exchange revenues and expenditures, to protect the economy of the Republic from the adverse effects of foreign competition, to facilitate the integration of the economy to the world economy, and to create new conditions for progressive changes in production and consumption, the Law on Customs Rate in new edition was adopted in 2013. The law provides for the application of tariff quotas on imports. This also allow regulating imports. Thus, if more goods are imported than government-imposed imports, then those excess commodities are used as a means of regulating imports using high customs duties. ${ }^{6}$ There are also certain discounts specified on customs duties.

By the decision of the Cabinet of Ministers of the Republic of Azerbaijan, 70\% of the goods imported to the country are exempt from all taxes and duties. ${ }^{7}$ All the goods imported to Azerbaijan under the oil contracts, several non-ferrous and non-ferrous metallurgy products, loans, grants, humanitarian aids, the products of non-resident employees of the companies working with foreign investment, all the industrial and non-commercial goods amounting less than $\$ 1000$ brought by the natural persons are not subject to any tax.

The Resolution No. 168 of the Cabinet of Ministers of April 26, 2016 on the approval of "Amounts of Customs Dues" states that the application of customs duties is not intended for domestic market protection and fiscal purposes. Their amount reflects the approximate value of the services provided by the customs authorities. Such services include customs control, customs clearance of goods, customs escort, storage of goods and other services.

Since 2016, "green corridor" system has been introduced to make customs clearance more flexible and transparent, and to develop the officer-business relationships based on modern management principles.

Legal entities and individuals, residents of industrial and technology parks and agricultural parks, who received investment promotion documents, are exempted from import duty for 7 years during the import of machinery, technology and equipment.

The Law on Antidumping, Compensation and Safeguards adopted in 2011 provides for the application of customs duties on dumped imports that damage local industries. ${ }^{8}$

\footnotetext{
${ }^{5}$ Tax Code of the Republic of Azerbaijan

${ }^{6}$ Law of the Republic of Azerbaijan Customs Control

${ }^{7}$ Law of the Republic of Azerbaijan on Customs Rate “Azarbaycan" Newspaper, 05.04.2015
}

${ }^{8}$ Resolution No. 168 of the Cabinet of Miniters dated 26 April 2016 on approval of "Amounts of Customs Dues

Law of the Republic of Azerbaijan on Antidumping, Compensation and Safeguards, 2016 
The changes made to the law in 2017 allow specific types of antidumping and countervailing duties to be applied if the increased volume and conditions of importation of the goods to the customs territory seriously hurt or threaten to cause serious damage. The procedure for the formation and application of these types of charges is determined by the investigating authority in accordance with the Law "On Antidumping, Compensation and Safeguards".

Implementation of the provisions of the mentioned law protects domestic production, on one hand, and protects domestic production on the other hand. Because some countries export the goods to Azerbaijan at a price lower than their normal value.

As more than 90 percent of the transnational business of Azerbaijan is composed of the oil and gas export operations, the Article is focused on regulation of foreign trade in this sector. The Law on Application of Special Economic Regimes in Export-aimed Oil and Gas Activities adopted in the country in 2009 regulates the regimens of the taxation, customs and currency regulation and the use of workforce by contractors and subcontractors. ${ }^{9}$

The goods (works, services) exported by contractors are subject to value-added tax at 0 (zero) interest rates. Contractors are entitled to require the excessively paid value-added tax refund from the state budget after replacing the full value-added tax on purchased goods (works, services) with existing tax liabilities.

Contractors and subcontractors are exempt from customs duties on the goods (works, services) imported by them to and from the Republic of Azerbaijan for export-aimed oil and gas activities (Article 4).

They are exempt from VAT on the goods (works, services) that they import to the Republic of Azerbaijan. They pay customs duties and value-added tax on the goods (works, services) imported and exported to the Republic of Azerbaijan for non-export-aimed oil and gas activities in accordance with the laws of the Republic of Azerbaijan.

Contractors and subcontractors are entitled to the right to freely transfer, store and use their own funds in foreign currency in the Republic of Azerbaijan after fulfilling their payment obligations (Article 5).

The Customs Code adopted in 2014 specifies that customs payments for goods imported to and exported from the customs territory in connection with execution of the Production Sharing Agreement, the Main Pipeline Agreement, and other international treaties shall apply in accordance with the provisions of the above mentioned agreements" (Article 235)..$^{10}$

According to "Rules of import-export operations in the Republic of Azerbaijan" adopted in 1997, all residents and non-residents in the Republic of Azerbaijan are free to carry out import-export operations and operate under "Customs Code", Law on "Customs Tariff", these "Rules" and other regulatory acts. ${ }^{11}$ According to the resolution No 91 of the

\footnotetext{
${ }^{9}$ Law of the Republic of Azerbaijan on Application of Special Economic Regimes in Export-aimed Oil and Gas Activities. Baku, 2 February 2009, No. 766-IIIQ

${ }^{10}$ Law of the Republic of Azerbaijan on Application of Special Economic Regimes in Exportaimed Oil and Gas Activities

${ }^{11}$ Customs Code adopted in 2014
} 
Cabinet of Ministers of the Republic of Azerbaijan dated 22 April 1998 "on the rates of customs duties on import-export operations in the Republic of Azerbaijan", exported goods were not subject to customs duties, regardless of their types (Article 3). ${ }^{12}$

Another resolution of the Government (No. 324; 31.08.2016), equipment and transmit antenna feeder systems for digital television broadcasting were also exempted from customs duties.

As specified by the Decree of the President of the Republic of Azerbaijan "on Additional Measures to Promote Export of Non-Oil Products" signed in 2016, transformation to export-aimed economy providing high added value has been set as a key goal based on a new economic reform model. ${ }^{13}$

One of the mechanisms to regulate transnational business in Azerbaijan is the taxation tool. The equipment, technology and technological units imported by the entrepreneurs from the time they received the investment promotion document are exempted from the customs duties for 7 years. At the same time, entrepreneurs are exempted from tax for 50\% of income of natural persons and profit of legal entities, as well as property and land tax, VAT for importation of equipment, technological plants and units under the proper confirming document for 7 years. Simultanously, studies are carried out to establish logistics centers in the contries of potential export markets, and works are performed to create an export database (electronic portal). Taking into account the importance of packaging that is of particular importance in exports, the establishment of organizations in this area is encouraged, and state support is enhanced to this field.

In 2013, Azerbaijan became a member of the Global Forum on Transparency and Exchange of Information for Tax of the Organization for Economic Cooperation and Development. The Ministry of Taxes is taking measures to improve tax information exchange with foreign countries and bring it into line with international standards.

Significant steps have been taken to improve the regulatory framework for importexport operations in 2016-2018. In 2018, the head of the country signed a decree "On measures to improve the system of control over import-export operations in the country" in order to improve transparency in the field of financial control, to simplify procedures for exporting non-oil products and to effectively coordinate the activities of state fiscal policy bodies. The decree envisages joint control of the Customs Committee and the Ministry of Taxes on a number of import-export operations.

According to the presidential decree "on measures to improve the system of control over import-export operations in the country", a new structure - the Import-Export Operations Department - was established under the Ministry of Taxes. ${ }^{14}$

Within the national legal systems, the TNB and its affiliates operating in the oil sector with regard to the practical measures in Azerbaijan are added to the group of special tax

\footnotetext{
12 Law of the Republic of Azerbaijan on Customs Tariff

${ }^{13}$ Decree of the President of the Republic of Azerbaijan on additional measures to promote export of non-oil products

${ }^{14}$ Decree on "Measures to improve the system of control on import-export operations in the country"
} 
regime taxpayers. First of all, it is necessary to strengthen tax control in relation to all types of TNBs and to improve its quality.

Taking into account the inherent variety of the TNBs with small businesses, it may be possible to modify or develop a single tax on potential income. For example, business evaluation criteria and justifications can be developed for each TNB individually, or even for each affiliates of TNB. This system, along with specialized tax accounting, will completely limit application of all methods of tax optimization and redistribution of revenues used by the TNB. If this is not possible to obtain it, then it would be advisable to merge the host countries, develop their common policies for the TNBs, as well as practical cooperation at the legislative, tax and law enforcement agencies.

Conclusion

So, presently there is no international-legal regulation of TNB activity and taxation issues require further elaboration and improvement in the future.

The main purpose of the fully effectively use of export capacity in the country is to ensure that the country's economy is directly dependent on non-oil export revenues. Macroeconomic sustainability should stand on exports of non-oil products. At the same time, it also requires a policy of strict control over import operations. One of the key principles in the effective control of import-export operations is that the rules of procedure are quite simple. It is also important to avoid increases in price in the mechanism of duties and taxes. The seriousness of this issue is that if the price of imported goods, for example, in the official car purchase documents is lower than the Azerbaijani car market, customs duty is calculated based on the local market and the payment is required from the importer. This approach is the legalization of corruption on one hand, while it is unjust on the other hand.

The reference of TNBs to the specific type of taxpayers and their registration with specialized tax authorities are considered appropriate. Here are the special requirements of tax accounting and control by tax service inspectorates against big taxpayers. In this case, the TNB, the country of origin of which is Azerbaijan, should consolidate taxation facilities in all its foreign branches in Azerbaijan. This should be done, for example, by establishment of a consolidated taxpayer or by incorporating provisions in the tax legislation regarding the expansion of Azerbaijan's tax jurisdiction with respect to all income and other tax items received by the TNB's overseas branches.

We think execution of regulation of the national companies of the host country as an economic subject, more efficient and competent laws, ensuring of transparency at the country level, at the same time, the fact that national companies of the country are ranked as transnational companies can create a balance in regulation of transnational business.

\section{Literature}

1. Tofig Huseynov, 2010, Investments in Azerbaijan, "Elm", p.51.

2. Law of the Republic of Azerbaijan on Protection of Foreign Investments. 2014

3. "Statistical indicators of Azerbaijan", State Statistics Committee, 2019

4. Law of the Republic of Azerbaijan on Subsoil. Baku, March 6, 2000; No. 351

5. The Contract of the Century, 1994

6. Presidential Decree No. 609 dated June 24, 1997 on Rules of Regulation of Import-Export Operations in Azerbaijan 
7. Tax Code of the Republic of Azerbaijan, Law No. 905IQ dated July 11, 2000

8. Law of the Republic of Azerbaijan on Export Control. Baku, October 2004, No. 772-IIQ

9. Law of the Republic of Azerbaijan on Customs Tariff. Baku, June 13, 2013. No. 687-IVQ

10. “Azerbaijan" newspaper, 05.04.2015

11.Resolution of the Cabinet of Ministers No. 168 dated April 26, 2016 on approval of Amounts of Custom Dues

12. Law of the Republic of Azerbaijan on "Antidumping, Compensation and Safeguards", Baku, No. 261-VQ, May 31, 2016

13. Law of the Republic of Azerbaijan on "Application of Special Economic Regime in Export-aimed Oil and Gas Activity", Baku, No. 766-IIIQ, February 2, 2009

14. "Customs Code", Law No. 164-IVQ dated June 24, 2011

15 .Law on Customs Tariff No. 687-IVQ dated June 13, 2013, Baku

16. Resolution of the Cabinet of Ministers of the Republic of Azerbaijan on Rates of Customs Duties on Import-Export Operations in the Republic of Azerbaijan; No. 91, April 22, 1998

17. Order of the President of the Republic of Azerbaijan on "Additional Measures to Promote Export of Oil and Gas Products", Baku, January 18, 2016

18. Order on "Measures to Improve the System of Control on Import-Export Operations in the Country", Baku, No. 260, June 28, 2018

19. Lokaychuk O.V. 2001. Problems of legal regulation of the activity of transnational corporations / O.V. Lokaychuk // Sibearian Legal Bulliten - No. 2. - p. 234-243.

20. Lukashuk I.I. 2001. Democracy, capital, statehood / I.I. Lukashuk // Journal of Russian law. - No. 1. - p. 222-226.

21. Chernichenko S.V. 1999. Territory of international law. In 2 vol. / S.V. Chernichenko. - M.: Theory, 1999. - Vol. 2. - p. 345

22. Natalukha V.V. 2005. International private business and statehood. / V.V. Natalukha - M.: Progress, - p. 356

23.. MacDougall, G.D.A. (1960), "The Benefits and Costs of Private Investikament from Abroad;A Teoretetical Appoad;EconomicRecord,Vol.36,13-35

24. Boutros Boutros-Ghali,2016, Former U.N. Secretary General, Dies at 93 - The New York Times. 